\title{
Policy and administrative barriers to IDPs accessing basic services
}

\author{
Luke Kelly \\ University of Manchester \\ 16 July 2021
}

\section{Question}

What are the barriers to IDPs accessing basic services, with a focus on administrative and policy barriers?

\section{Contents}
1. Summary
2. Definitions and background
3. Barriers to accessing services
4. References

The K4D helpdesk service provides brief summaries of current research, evidence, and lessons learned. Helpdesk reports are not rigorous or systematic reviews; they are intended to provide an introduction to the most important evidence related to a research question. They draw on a rapid deskbased review of published literature and consultation with subject specialists.

Helpdesk reports are commissioned by the UK Foreign, Commonwealth, and Development Office and other Government departments, but the views and opinions expressed do not necessarily reflect those of FCDO, the UK Government, K4D or any other contributing organisation. For further information, please contact helpdesk@k4d.info. 


\section{Summary}

Literature shows that IDPs struggle to access services, which has an impact on their ability to live healthy and fulfilling lives. In the field of health, IDPs frequently have worse outcomes than both host community and refugees. This rapid literature review finds evidence of a number of policy and administrative barriers to access of services for internally displaced persons (IDPs). Chief among these barriers are the need for identification (ID) documentation, which may have been lost, destroyed or be hard to obtain, to access services; that IDPs may struggle to access services if they are registered in their place of origin, but not their displaced locality; and that national and international policies and programmes often do not target the specific needs of IDPs or ways to overcome these barriers.

IDPs remain citizens of the countries in which they are displaced, and the national authorities retain responsibility for meeting their basic rights. However, their displacement, loss of livelihoods and assets, lack of documentation, as well as discrimination against them, lack of protection under international law, lack of policy to address their needs, poor services and conflict or disaster conditions, can all make it more difficult for IDPs to access basic services than non-displaced citizens. The condition of IDPs, including access to services, is therefore shaped by a number of factors, may vary from context to context.

The main administrative and policy barriers identified are:

- A lack of data on IDPs at the national or local level;

- Service provision by local government requiring local residency status.

- IDP having reduced access to their rights as citizens due to their displacement.

- A lack of policy focus on IDP needs in many states;

- Unclear divisions of responsibilities between local and national government departments for IDPs;

- Relatively weak international law and guidance;

- A lack of documents, lost documents or difficulties getting documents (e.g. the need to return to the place of displacement to acquire new documents);

- Failure to adapt bureaucratic systems to IDP needs (e.g. language and literacy barriers; IDPs lack of awareness of entitlements or how to get them);

- Discrimination by bureaucrats against IDPs;

- Targeting by status meanings vulnerable people who do not have formal status are unable to receive support, in particular in urban areas. This is often the case when there is a stronger focus on refugees based on their status not their need.

There is relatively little literature systematically addressing the issue of administrative and policy barriers to service access among IDPs. Much of the literature discusses IDPs alongside refugees (who have a different legal status and access to different national and international support), or discusses the whole range of difficulties facing IDPs but does not focus on administrative or policy barriers. The literature frequently does not compare IDPs and other citizens and service users. Nevertheless, policy and administrative barriers are discussed, ranging from analysis of international instruments on IDPs to documentation procedures in particular countries. Much of the literature shows the prevalence of disease, lack of school attendance, limited provision of services 
etc. faced by IDPs, but does not discuss the policy and administrative barriers in detail. However, issues relating to documentation and policy on IDPs and services are mentioned in many reports on IDP situations. There is some discussion of gender and, to a lesser extent, disability.

\section{Definitions and background}

Internally displaced persons (IDPs) are defined as 'persons or groups of persons who have been forced or obliged to flee or to leave their homes or places of habitual residence, in particular as a result of or in order to avoid the effects of armed conflict, situations of generalised violence, violations of human rights or natural or human-made disasters, and who have not crossed an internationally recognised border. ${ }^{11}$ At the end of 2020 , there were estimated to be 55 million IDPs globally. ${ }^{2}$

IDPs are often subject to 'deprivation, further displacement and other protection risks, such as lack of access to basic services, family separation, sexual and gender based violence, trafficking, discrimination and harassment. ${ }^{3}$ They remain within their country of citizenship, and therefore retain de jure the rights and guarantees of citizenship. This often includes the equal right to services. National authorities are responsible for protecting IDPs. ${ }^{4}$ However, in cases where the government is responsible for the displacement, this protection may have limited value (Ferris \& Winthrop, 2010, p. 7). Governments in states where displacement occurs may also lack the capacity and resources to provide basic services to displaced, and other, populations. IDPs do not receive the same protections in international law as refugees, although they may in practice share some of the same characteristics and needs (e.g. as forced migrants) (Kalin, 2014). The IDP label may itself lead to discrimination or particular entitlements (Brun, 2003; Oosterom, 2016).

Basic services are taken to be water, sanitation, shelter, healthcare, education and other similar services. IDPs have the right to the same services as other citizens, but may in practice rely on humanitarian aid for survival.

There are a number of barriers to IDPs accessing services. These include:

- IDPs may live in informal settlements where there are limited services (Ferrández, 2020a).

- In areas affected by conflict, infrastructure may have been destroyed (Grayson \& Cotroneo, 2018).

- IDPs may have reduced assets and livelihoods, making it hard for them to afford user fees, or meaning children have to work instead of attending school.

- IDPs may be targeted by state or non-state armed forces, or subject to community and administrative discrimination.

\footnotetext{
1 As defined by the UN's Guiding Principles on Internal Displacement. https://www.ohchr.org/en/issues/idpersons/pages/issues.aspx

2 https://www.internal-displacement.org/database/displacement-data

${ }^{3}$ https://emergency.unhcr.org/entry/44826/idp-definition

${ }^{4}$ https://emergency.unhcr.org/entry/44826/idp-definition
} 
However, this literature review focuses on barriers of a political or administrative nature (i.e. those not related directly to socio-economic, disaster or conflict conditions). These include policy attention given to IDPs; eligibility requirements favouring citizens registered in a particular local government area for accessing services; documentation requirements; and other related issues.

\section{General findings and issues}

In general, research and policy papers point to the difficulties IDPs have in accessing services. For instance, a 2021 workshop on health and internal migration reported: 'limited access to health services was felt to be a potentially significant factor affecting IDP health. Health systems may already be stretched before the influx of IDPs and may struggle to manage extra demands. IDPs may also be disadvantaged by lack of agreed packages of care and inadequate integration into referral systems for more specialist care' (Academy of Medical Sciences, 2021, p. 10).

A key determinant of IDPs' access to services is whether they reside in or outside of camps (Brookings Institute, 2013; Cotroneo, 2017). IDPs in camps are easier to target with humanitarian assistance but IDPs outside of camps, and particularly in urban areas, often have access to a greater range of services. ${ }^{5}$ However, access to services in both camps and outside of camps varies from context to context. IDPs in informal urban settlements may have access to only a very limited range of services, for example (World Bank, 2017, pp. 70-71). The reason for displacement, the resources and availability of services in the place of displacement, and national service delivery structures, are other relevant factors.

The IOM provides data on access to services in rural $v$ urban areas in Nigeria and Ethiopia, based on its displacement ranking matrix (DTM). It provides data on access to services, but not quality of services or obstacles to access (IOM, 2019, p. 17). The data supports the idea that there is greater access to services in urban areas than rural areas (IOM, 2019, p. 18). This is consistent with evidence of higher provision of services in urban areas see (Central Statistical Agency (CSA) [Ethiopia] and ICF, 2016; National Population Commission (NPC) [Nigeria] and ICF, 2019). In Nigeria, access to services up to ten percentage points higher in urban than rural. However, it points to the need for qualitative assessment of needs to understand the quality of services and why they were or were not used (IOM, 2019, p. 20).

A report looks at IDPs' self-reported satisfaction with health and education services 'in urban areas of post-socialist countries of Central and Eastern Europe that experienced violent conflict in 1990s and 2000s' (Ivlevs, 2019, p. 3). Data comes from the Life in Transition-II survey conducted by the European Bank for Reconstruction and Development and the World Bank in 2010. It finds greater rates of dissatisfaction with health services among IDPs than others. Dissatisfaction takes the form of disrespectful treatment by staff, lack of medication, long waiting lists/lines, unclean facilities, as well as requests for unauthorised payment for services that should be free. This may be because of a concentration of IDPs in areas with poorer services, or prejudice against IDPs. Better outcomes were reported in education (Ivlevs, 2019).

${ }^{5}$ https://blogs.worldbank.org/dev4peace/displacement-camps-better-or-worse 


\section{Administrative and policy barriers to accessing services}

\section{National and international policy}

The UN's Guiding Principles on Internal Displacement (1998) is the main international document outlining principles for protecting IDPs. ${ }^{6}$ The guiding principles include rights 'to an adequate standard of living; to medical care...political participation, and communication, and to education. This also includes a right to be recognized before the law, with the authorities needing to issue them all documents necessary for this including either new document or replacement of documents lost in the course of displacement' (Orchard, 2018, p. 8). The African Union Convention for the Protection and Assistance of Internally Displaced Persons in Africa (Kampala Convention, 2009) is a binding instrument based on the Guiding Principles, that emphasises the responsibility of states (Dieng, 2017). It 'requires states parties to enact appropriate legislation, create an institutional framework for the coordination of IDP-related activities, and allocate the necessary funds to ensure implementation' (Kalin, 2014).

Some scholars argue that the status of IDPs in international law leads them to have less protection and access to services (Rae, 2011). The treaties and instruments from which they derive rights are less well monitored and enforced than those for refugees - for instance, the UN's guiding principles are non-binding, meaning there is less pressure on states to fulfil obligations to IDPs. Agencies have at times prioritised aid to refugees over IDPs (Rae, 2011). A lack of ratification of international human rights conventions can hinder efforts to improve documentation for IDPs (Tull, 2019). However, OCHA has a mandate for the coordination of assistance to IDPs ${ }^{7}$ and the UNHCR provides assistance to IDPs via the cluster system. ${ }^{8}$

Research highlights that the implementation of international guidelines is limited. Even if states refer to the UN guiding principles, 'studies emphasise that the content of the diverse national laws and policies rightly reflects the specific circumstances of IDPs in each country' (Cantor and Woolley, 2020, p. 14). In measuring the diffusion of the Kampala Convention, the ICRC shows that some 'states have adopted laws, policies and/or other measures to protect and assist IDPs based on the obligations set out in the Kampala Convention without actually signing or ratifying it', although it may be too early to tell if such measures are being implemented effectively (ICRC, 2020). A review of national laws and policies finds that not many national laws on IDPs explicitly mention the guiding principles, or define IDPs. Some define IDPs with geographical or temporal limitations (Orchard, 2018, p. 8; Kalin, 2014). Moreover 'bodies [for assisting IDPs] are frequently underfunded, under-resourced, and lack clear lines of authority within government' (Orchard, 2018, p. 13; Kalin, 2014). It is also argued that there is no need for specific bodies and that IDPs should be treated alongside other citizens, in particular in the context of urban policy (Nunez-Ferrera et al., 2020).

\footnotetext{
${ }^{6}$ https://www.unhcr.org/uk/protection/idps/43ce1cff2/guiding-principles-internal-displacement.html

${ }^{7}$ https://www.unocha.org/themes/internal-displacement

${ }^{8}$ https://www.unhcr.org/uk/internally-displaced-people.html
} 
Governments may see IDPs as a security threat or a poverty problem, and focus on encouraging their return rather than policies that may help integrate IDPs. Examples of Iraq and Nigeria are given (Grayson \& Cotroneo, 2018, p. 25). IDPs may face discrimination based on being displaced and/or perceived associations with armed groups when attempting to access services (Brookings Institute, 2013, p. 6)

Governments may overlook IDPs in the provision of services. For example, research on 16 conflict-affected countries' immunisation coverage found that only one of the multi-year immunisation plans mentions IDPs or displaced populations (Grundy and Biggs, 2018, p. 215). Research on Iraq's universal food subsidy programme, the Public Distribution Programme (PDS), shows disparities in access: 'Forced migrants with PDS access are likely to be residing in the present governorate for a longer duration, and settled in a rural place, especially in the Northern region of the country. In contrast, their PDS non-recipient counterparts have significantly greater odds of residing in the Kurdistan region' (Phadera et al., 2020, p. 7).

However, governments and others may also argue that IDPs' needs do not significantly differ from those of other vulnerable citizens (Kalin, 2014; Kamungi, 2013). Indeed, there is considerable debate 'as to whether or not it is meaningful to look at IDPs as a distinct category of concern' (Kalin, 2014, p. 166).

Humanitarian aid may be provided to IDPs in many cases. However, it may not always meet the needs of IDPs, particularly after an 'emergency' phase of support (Ferris \& Winthrop, 2010). Research from Afghanistan shows how the 'lack of an effective transition from humanitarian crises to development initiatives had led to a funding and programmatic gap' (Parwak, 2019, p. 6). In some cases, IDPs may only receive help if they are in official camps, leaving self-settled IDPs with limited access to services (Ekezie et al., 2019). Humanitarians may struggle to identify IDPs needing help in urban environments, as well as to collaborate with the range of governmental and non-governmental actors, at local and national level, involved in urban service provision (Cotroneo, 2017). Despite barriers many IDPs do access social protection to meet their food needs, however, they face barriers and better understanding of what factors drive inclusion and exclusion will help to develop better policy to include IDPs.

\section{Data}

Data on IDPs is collected by different actors using different methods, meaning there are gaps and inconsistencies (Cantor \& Woolley, 2020, p. 16; World Bank, 2017, p. 30). In addition, figures may be manipulated by authorities wishing to decrease or increase the official number of IDPs for political or resource reasons. For their part IDPs may, for security reasons, be wary of state information gathering (Brookings Institute, 2013).

In particular, there is 'a striking lack of accurate data on IDPs outside camps' (Brookings Institute, 2013, p. 7). There are several reasons for this: 'IDPs living outside camp situations tend to remain an invisible group, even though they constitute the largest proportion of all forcibly displaced populations. In contexts like Somalia, where groups are traditionally nomadic and have experienced protracted crises, distinguishing whether people are living in their current homes due to forced displacement, nomadic displacement, or urban migration becomes difficult, and is further complicated by the fact that targeting of humanitarian aid to IDPs may encourage self-identification as IDPs' (Bengtsson \& Naylor, 2016, p. 30). With respect to services, a 2016 report on displacement and education finds that there is an evidence gap on IDPs outside of camps 
(Bengtsson \& Naylor, 2016). For example, a recent study highlights a lack of information on IDPs displaced by the non-state armed group Boko Haram in Nigeria (Ekezie et al., 2019).

A lack of data on IDPs can also be a consequence of government policies and data collection practices. A study of Colombia shows how 'government agencies and NGOs presented vastly disparate statistics, with government figures showing much lower estimates of the amount of internally displaced persons, or IDPs' (Oslender, 2016, p. 10). Government statistics leave out those who are afraid to register, unaware of the need, lack documents or who do not see the benefit of the status. Registration is needed to receive emergency help. A 2011 study of Colombia found $34 \%$ of IDPs were not registered, and $25 \%$ of applicants were turned down (Oslender, 2016). In addition, the lack of reliable data on Afro-Colombian IDPs means aid is not always targeted appropriately, and the differentiated ways they are affected by the conflict was not taken into account (Oslender, 2016).

A report on IDPs living in urban areas in Kenya following political violence finds that a lack of data is one barrier to providing adequate services for IDPs (Kamungi, 2013). This is because (Kamungi, 2013):

- Municipalities in Kenya do not monitor population dynamics. They use data from the National Bureau of Statistics, but this is not disaggregated for IDPs or urban migrants.

- A low rate of registration among IDPs living in urban settings.

- Municipalities do not plan for IDPs, and do not differentiate between IDPs and the rest of the urban poor.

- National plans for IDPs were based on certain assumptions that excluded many IDPs from help: a focus on land for farmers, despite many IDPs working in cities; assumptions that the displaced owned their homes; and the assumption that the difficulties of displacement end when camps are closed.

The lack of data on IDPs mean that IDP needs, and the needs of particularly vulnerable IDPs, may not be registered and provided for in services. Displaced persons with disabilities living in camps may find basic facilities such as food distribution centres, water collection points, sanitation facilities, schools, health centres and administrative offices inaccessible due to a lack of consideration in design (Mirza, 2014). For example, analysis of IDP sites in NW Syria finds (Protection Cluster, 2020, pp. 10-20):

- 'physical terrain in many areas of northwest Syria is often inaccessible for persons with disabilities' (Protection Cluster, 2020, p. 10).

- 'universal design of service facilities is lacking, creating a significant barrier to service access' (Protection Cluster, 2020, p. 10).

- 'persons with disabilities may rely on non-verbal communication, staff are often not able to accommodate these needs' (Protection Cluster, 2020, p. 11).

- There are also barriers to persons with disabilities accessing help from humanitarian organisations.

Displaced persons with disabilities are also likely to face problems deriving from physical inaccessibility outside of camps. This is because 'urban settlements where displaced populations 
seek refuge are frequently located in impoverished regions of the world, which lack legal regulations and mandates promoting accessibility for people with disabilities' (Mirza, 2014).

\section{Documentation}

Documentation is widely cited as a barrier to IDPs accessing services (Tull, 2019). Outside of IDP camps, papers are often required. They are needed for school, healthcare and housing. Such requirements make it hard for IDPs to access services. According to a UNICEF report, 'internally displaced children in urban settings face significant challenges in accessing services without registration and documentation' (UNICEF, 2019, p. 7). A report on IDPs in Adama, Ethiopia shows that IDP cards, which many lack, are necessary to receive food and healthcare (EastonCalabria, 2020); a survey of the Somali region of Ethiopia found that only $13 \%$ of both hosts and IDPs reported having a national identity card, needed to access services (Ferrández, 2020b). It is worth highlighting that the issue affected both IDPs and other poor citizens.

Paper-based systems can make it harder for IDPs to obtain new or replacement documents. 'Retrieving birth registration records, issuing a duplicate copy of a birth certificate, or sharing civil registration data with other relevant agencies can be ineffective and time consuming with paperbased systems' (Tull, 2019, p. 12). Researchers therefore recommend the development of digital solutions, or the use of trust-based systems (e.g. testimony from local mayors etc), to enable IDPs to access services more easily, particularly in conflict-affected contexts (Tull, 2019).

Procedures for obtaining documents often make it difficult for those who have been forced to move. In Iraq and other countries, ID can only be obtained from the place where a citizen is originally registered, which makes it hard for IDPs (Cotroneo, 2017; Tull, 2019). IDPs may be reluctant to register in their new location from fear of threats to their family, if the municipality from which they fled must confirm their identity, as has been found in Colombia (Davidovic et al., 2018, p. 9; Ibáñez and Velásquez, 2008). IDPs in Ethiopia 'face difficulties in claiming entitlements to the Productive Safety Net Programme (PSNP, which is part of the prevention and mitigation activities) due to administrative barriers for registration in the area of displacement and conflict' (Meskele Ashine, 2021).

Bureaucratic requirements for accessing services tend to be greater in cities than the countryside. Thus, 'people displaced in cities often face legal and administrative barriers that limit their ability to work, settle, secure tenure or access urban services. Difficulties can be especially acute for people arriving from the countryside: they may be unfamiliar with the legal and administrative system or may lack the necessary official documentation to gain access to services or State assistance, or to rent or buy a property; in fact, such documents might not have been necessary in rural areas, or might have been left behind or lost during flight' (Grayson and Cotroneo, 2018, p. 25). Newcomers to an urban area may not know how to access services, or who to ask, or may not speak the official language or be able to read and write (Cotroneo, 2017).

Administrative arrangements may favour particular groups, and make it harder for others:

- For instance, in Iraq, ration cards are given to male heads of households (UNICEF, 2019). This makes it hard for female- or child-headed IDP households to access rations.

- In Uganda, ration cards are given to IDPs in camps, but not others (UNICEF, 2019). 
- In Afghanistan, identity cards are needed to access education, but are only issued in one's areas of origin, making it hard for IDPs to access education. Birth certificates are needed to access healthcare, and immunisation records for further vaccinations (UNICEF, 2019).

- In Georgia, IDPs are eligible for health insurance schemes, but their complexity means it is difficult to for IDPs or service providers to understand IDPs' entitlements (Tull, 2019).

- In Ukraine, 'amendments to the IDP law neither clarified whether previously issued IDP certificates will remain valid after their expiration date, nor stipulated a procedure for exchanging previously issued certificates for ones with no expiration date. This has caused a situation where thousands of IDPs with expired IDP certificates cannot renew them' (Tull, 2019, p. 9).

A 2007 UNHCR report on IDPs in Serbia highlights a number of policy and administrative barriers to service utilisation. It states that 'IDPs often face barriers and obstacles in the realization of basic rights, including difficulties such as: - Securing basic documents required to access social and humanitarian assistance; • Registering residence; • Finding suitable and stable basic accommodation; and, - Accessing employment and collecting pensions' (UNHCR, 2007, p. 4). Documents are required to access services, and are difficult to obtain: for lack of a birth certificate, the IDP could not obtain an identity card and for lack of an identity card, the IDP could not access housing and employment without which she/he became homeless' (UNHCR, 2007, p. 17).

\section{Problems accessing documents included (UNHCR, 2007):}

- That IDP cards were not issued to persons originating in Kosovo;

- The need to travel to obtain documentation in 'dislocated registry offices';

- Some documents required applicants to present several documents from within the past six months, which requires frequent and costly travel to offices;

- Many documents required fees and, although reductions are available, they were not advertised;

- Long processing times, and lack of digitised documents;

- Those living in unofficial temporary accommodation could not access government or humanitarian support.

In addition Roma, Ashkaeli and Egyptian communities (RAE) IDPs faced 'language and cultural barriers and overt and subtle discrimination by health care providers' and other service providers (UNHCR, 2007, p. 42). This is despite government policies on RAE.

In Iraq, difficulties obtaining documentation are creating a number of barriers to service access for IDPs. A Norwegian Refugee Council (NRC) study finds that of those displaced in Iraq by Islamic State (IS) 'about 45,000 children displaced in camps today do not have Iraqi-state issued birth certificates or other civil documents proving their legal identity' (Saieh, 2019, p. 3). Without identification they may not be able to access schools, healthcare etc. 'A combination of the civil ID and other state-issued documents, including the Public Distribution System (PDS), nationality card, and housing card, are required to access a range of public services in Iraq'; enforcement of these requirements may be patchy, but is likely to affect those formerly living under IS (Saieh, 2019, p. 11). The lack of documentation has been brought about by IS confiscation of previous documents, and the current state refusing to accept IS-issued documentation. Iraqi security forces have 
confiscated the documents of some who they believe were affiliated with IS in some way (Saieh, 2019 , p. 3). In addition, many who are believed to have been associated with IS face discrimination in accessing services and documents.

IDPs find it difficult to obtain new documentation because the Iraqi civil service is under-resourced and busy. Certain groups face additional barriers:

- Women with dead or missing husbands need to prove the circumstances of their husband's death to obtain necessary documents.

- 'children whose parents are undocumented, are on one of the government's security databases or are perceived to be affiliated with IS face much greater difficulties accessing legal documentation' (Saieh, 2019, p. 7).

National policies have done relatively little to overcome these difficulties. Iraqi counter-terrorism laws often result in discrimination against Iraqis who lived under IS rule. There are 'unclear and at times contradictory reports of directives issued by the Iraqi authorities on the issuance of civil IDs for families, including children with perceived affiliation to IS group members" (Saieh, 2019, p. 22). An NRC study finds a 2018 Ministry of Education directive has had limited success in allowing undocumented children to attend school (Saieh, 2019). National policies do not call for ID in seeking medical help, but in practice it may often be required, especially for serious procedures. ID is often needed at checkpoints when travelling. IDPs without ID may therefore find it difficult to access health services in other settlements. Corruption in the civil service means bribes are sometimes needed to obtain documents.

There are a number of barriers to Rohingya IDPs accessing healthcare (beyond low levels of health provision in Myanmar overall) (Debarre, 2019). Referral to hospitals for IDPs in camps is a 'cumbersome and time-consuming process' (Debarre, 2019, p. 14). It involves significant travel, and payment of bribes. Rohingya are likely to be abused/detained at military checkpoints. There are also language and cultural barriers for Rohingya IDPs in Rakhine state, as most health workers are Rakhine. In addition, NGOs are barred from accessing some regions with large numbers of IDPs, such as Shan, which reduces the availability of healthcare (Debarre, 2019).

\section{Organisation of government}

While ultimate responsibility for IDPs rests with national authorities, local authorities are likely to be in charge of the provision of basic services (Brookings Institute, 2013, p. 16). However, they often lack the resources to provide sufficient services. In addition, coordination between national and local government is often poor. A report by the Brookings Institute highlights the 'technical challenge' of assessing the needs of IDPs, registering them, applying for funds, which all act as disincentives to providing services (Brookings Institute, 2013). Research on Kenya shows a lack of specific mandates or clear division of responsibility between ministries and municipalities (Kamungi, 2013).

Local government may attempt to discourage IDPs. 'In some countries, such as Iraq, provincial governments limit the movement of IDPs into their territories, creating de facto borders' (Ferris and Winthrop, 2010, p. 25). Local government "may be reluctant to encourage the integration of IDPs in the city, including through urban development schemes, as this could act as a 'pull' factor for IDPs and migrants" ("Under the radar: IDPs outside of camps", 2013, p. 21). For example, Afghan 
slums in Kabul have not been developed for this reason, and lack sufficient, electricity, water and other services.

There is evidence of bureaucratic barriers to IDPs accessing services. For example. 'local health and educational institutions may request proof of residency or special fees from IDP families (for services normally provided free of charge) in order to expand their services to them' (Brookings Institute, 2013, p. 22)

A 2011 report from Iraq by the UN's Special Rapporteur on IDP rights found 'that IDPs are often denied access to basic services such as primary education and health services, due to the fact that local schools or health facilities are already underfunded or overcrowded, or for purely bureaucratic reasons' (Brookings Institute, 2013, p. 22). For example, IDPs were unable to transfer food ration cards to different local authorities.

Research on Muslim IDPs in Sri Lanka around 1998-2000 finds that the IDP label contributed to a lack of access to services. 'The responsibility for assistance and protection of IDPs in Sri Lanka is divided among many government and governmental departments. The involvement of such a large number of ministries and departments has caused bureaucratic delays and gaps in assistance, and also considerable confusion among the parties involved (the IDPs, NGOs, aid agencies and the ministries) about what is the current policy on IDPs, and who has the responsibility' (Brun, 2003, p. 383). A 1995 resettlement scheme focused on resettling IDPs in their place of origin, meaning 'IDPs who [found] themselves outside the administrative regions where they [were] registered have problems in keeping up the relationship with the state which characterizes Sri Lankan citizenship' and could not access services (Brun, 2003, p. 383). Many were 'unwilling or unable' to change their registration to their new location because of the need to return to their place of origin to register, at personal risk, and the fear that it would reduce their chances of permanently returning to their place of origin (Brun, 2003).

Research on Colombia finds that there are few services in informal urban areas where many IDPs reside. Research into the informal settlement of Altos de la Florida in Soacha, Colombia finds that the settlement is not considered part of the town by the municipal authorities. It needs to be legalised before residents can access services. The 'neighbourhood does not have a mains water or sewage system' (Ferrández, 2020a, p. 9). The research also points to differences between rural and urban curriculums, which means that IDPs from rural areas may need to repeat years. It also highlights the need for documentation to enrol children in schools (Ferrández, 2020a).

\section{Education}

A review of education and displacement finds that there is a lack of data on education and IDPs, and situations vary by context. Many IDPs are not in schools, but the exact figure is not known and figures are highly context-dependent (Bengtsson \& Naylor, 2016).

The 'availability of education depends on government policies, either of host governments in the case of refugees or national governments in the case of IDPs' (Ferris and Winthrop, 2010, p. 22). 'When governments are involved in the conflict, such as Sudan or DRC, education usually is a subordinate priority to waging the conflict itself' (Ferris and Winthrop, 2010, p. 22).

Humanitarian actors may provide education, but 'education is less likely to be available in the emergency phase of displacement as international and national actors focus on security 
and on provision of basic necessities of life' (Ferris and Winthrop, 2010, p. 22). 'International support for education for IDPs is generally treated as a short-term humanitarian response; however, many IDPs live in protracted displacement. Education tends to be a high priority for IDPs themselves, but has tended to be a low priority for humanitarian actors' (Bengtsson and Naylor, 2016 , p. 10). There, however, is evidence that humanitarian funding for education is increasing following recent policy changes, with the EU pledging $10 \%$ of its humanitarian aid budget to education and a global increase to $4.3 \%$ of humanitarian aid being spent on education in 2018. ${ }^{9}$

There is more outside provision in camps than outside of camps, where humanitarian actors have to negotiate with local authorities (Ferris and Winthrop, 2010, p. 23). IDPs outside of camps 'tend to receive less access and support from international humanitarian organisations, but may have better access to local schools' (Bengtsson and Naylor, 2016, p. viii).

\section{Difficulties accessing education are created by:}

- The need for certification of learning attainment, and problems obtaining it (Ferris and Winthrop, 2010, p. 23);

- IDPs often lack school certificates needed to transfer (Ferris and Winthrop, 2010);

- The loss of documentation and residency requirement;

- Language barriers and discrimination;

- A lack of infrastructure, teachers, unsafe journeys/schools, school fees, materials, the need to work and health issues are all barriers to IDP school attendance;

- For women, gender-based violence, discrimination, lack of toilets, early marriage and childbearing, and lack of sanitary supplies all act as barriers to school attendance;

- IDPs outside of camps 'may experience discrimination, as reported by IDPs in Colombia, Azerbaijan, and Sudan' (Bengtsson and Naylor, 2016, p. 43);

- IDPs outside of camps 'may have concerns about their children attending schools in unfamiliar settings' (Bengtsson and Naylor, 2016, p. 43);

- IDPs outside of camps 'may have better access to government schools or low-cost private schools' (Bengtsson and Naylor, 2016, p. 43);

- Local governments lacking resources for education (Ferris and Winthrop, 2010, p. 25);

- IDPs are often supported by humanitarian funding, which does not focus on funding education, although there has been more funding since 1999 (Bengtsson and Naylor, 2016, p. 32);

- 'IDP camp residents are often provided with food rations; however, the distribution of these rations can inadvertently act as a barrier to education as collecting and transporting them is a common cause of absenteeism' (Bengtsson and Naylor, 2016, p. 29);

- 'IDPs in camps may have access to non-formal learning spaces or primary schools supported by the international community, but have very limited access to secondary education' (Bengtsson and Naylor, 2016, p. 9).

\footnotetext{
${ }^{9}$ See https://www.educationcannotwait.org/about-us/
} 


\section{References}

Bengtsson, S., \& Naylor, R. (2016). Topic guide on Education for refugees and IDPs in low- and middle-income countries: Identifying challenges and opportunities. Heart. https://www.heart-resources.org/topic/education-for-refugees-and-idps/

Brookings Institute. Under the radar: IDPS outside of camps. (2013). https://www.brookings.edu/wp-content/uploads/2016/06/Under-the-radarIDPs-outside-ofcamps-Oct-2013.pdf

Brun, C. (2003). Local Citizens or Internally Displaced Persons? Dilemmas of Long Term Displacement in Sri Lanka. Journal of Refugee Studies, 16(4), 376-397. https://doi.org/10.1093/jrs/16.4.376

Cantor, D. J., \& Woolley, A. (2020). Internal Displacement and Responses at the Global Level: A Review of the Scholarship. https://sas-space.sas.ac.uk/9356/

Central Statistical Agency (CSA) [Ethiopia] and ICF (2016). Ethiopia Demographic and Health Survey 2016. https://dhsprogram.com/pubs/pdf/FR328/FR328.pdf

Cotroneo, A. (2017). Specificities and challenges of responding to internal displacement in urban settings. International Review of the Red Cross, 99(904), 283-318. https://doi.org/10.1017/S1816383118000164

Davidovic, G., Herm-Singh, S., \& Stuttgen, L. (2018). Internally displaced people and their access to health care in the metropolis: The case of Bogota. Inclusivity Lab. https://en.unesco.org/inclusivepolicylab/system/files/teams/document/2018/2/il-2internally-displaced_0_0_0_0_0.pdf

Debarre, A. (2019). The Humanitarian Response in Myanmar. International Peace Institute. https://www.ipinst.org/wp-content/uploads/2019/02/1902_Delivering-Healthcare-inMyanmar.pdf

Dieng, A. (2017). Protecting internally displaced persons: The value of the Kampala Convention as a regional example. International Review of the Red Cross, 99(904), 263-282. doi:10.1017/S1816383117000613

Easton-Calabria, E. (2020). Success Twinned by Challenge: An Urban IDP Response in Ethiopia. Refugee Survey Quarterly, 39, 525-536. https://doi.org/10.1093/rsq/hdaa033

Ekezie, W., Timmons, S., Myles, P., Siebert, P., Bains, M., \& Pritchard, C. (2019). An audit of healthcare provision in internally displaced population camps in Nigeria. Journal of Public Health, 41(3), 583-592. https://doi.org/10.1093/pubmed/fdy 141

Ferrández, P. C. (2020a). From aid to empowerment: Addressing urban displacement in Colombia's informal settlements. IDMC. https://www.internaldisplacement.org/sites/default/files/publications/documents/IDMC_UrbanDisplacement_C olumbia_EN_final.pdf

Ferrández, P. C. (2020b). From basic needs to the recovery of livelihoods: Local integration of people displaced by drought in Ethiopia. IDMC. https://www.internal- 
displacement.org/sites/default/files/publications/documents/21_0318_Local_integration_i n_Ethiopia.pdf

Ferris, E., \& Winthrop, R. (2010). Education and Displacement: Assessing Conditions for Refugees and Internally Displaced Persons affected by Conflict. UNESCO. https://www.brookings.edu/wp-content/uploads/2016/06/2011_02_idp_unesco_ferrise.pdf

Grayson, C.-L., \& Cotroneo, A. (2018). Displaced in Cities: Experiencing and responding to urban internal displacement outside camps. ICRC. https://reliefweb.int/sites/reliefweb.int/files/resources/4344_002_Displaced-in-

Cities_web.pdf

Ibáñez, A. M., \& Velásquez, A. (2008). Public policies to assist Internally Displaced Persons: the role of municipal authorities. Brookings Institution-University of Bern Project on Internal Displacement.

https://www.researchgate.net/publication/228389181_Public_Policies_to_Assist_Internall y_Displaced_Persons_The_Role_of_Municipal_Authorities

ICRC (2020). The Kampala Convention: key recommendations ten years on. ICRC. https://www.icrc.org/en/document/kampala-convention-key-recommendations-ten-years

IOM. (2019). Internal displacement in urban and rural areas: An analysis of IDP distribution and access to services in Nigeria and Ethiopia. https://displacement.iom.int/system/tdf/reports/urban_displacement_21-0519.pdf? file $=1 \&$ type $=$ node\&id $=5739$

Ivlevs, A. (2019). Are IDPs satisfied with the quality of public health and education services they receive? https://www.internal-displacement.org/globalreport/grid2019/downloads/background_papers/IvlevsArtjoms_FinalPaper.pdf

Kalin, W. (2014). Internal Displacement. In The Oxford Handbook of Refugee and Forced Migration Studies.

https://www.oxfordhandbooks.com/view/10.1093/oxfordhb/9780199652433.001.0001/oxf ordhb-9780199652433-e-019

Kamungi, P. (2013). Municipalities and IDPs outside of camps: The case of Kenya's integrated displaced persons. Brookings Institute-LSE. https://www.brookings.edu/wpcontent/uploads/2016/06/IDP-Municipal-Authorities-Kenya-May-2013-FINAL.pdf

Meskele Ashine, E. (2021). The Adequacy of Law and Policy Frameworks on Internal Displacement in Ethiopia: A Critical Appraisal. National Protection of Internally Displaced Persons in Africa, 27-36. https://doi.org/10.1007/978-3-030-66884-6_4

Mirza, M. (2014). Disability and Forced Migration. In The Oxford Handbook of Refugee and Forced Migration Studies. https://doi.org/10.1093/oxfordhb/9780199652433.013.0040

National Population Commission (NPC) [Nigeria] and ICF (2019). Nigeria Demographic and Health Survey 2018. https://dhsprogram.com/pubs/pdf/FR359/FR359.pdf

Nunez-Ferrera, I. et al. (2020) IDPs in towns and cities - working with the realities of internal displacement in an urban world, Submission to the UN Secretary-General's High-Level 
Panel on Internal Displacement by IIED, JIPS and UN-Habitat. https://www.jips.org/jipspublication/working-with-the-realities-of-internal-displacement-in-an-urban-world-jips-iiedunhabitat-may2020/

Oosterom, M. A. (2016). Internal Displacement, the Camp and the Construction of Citizenship: Perspectives from Northern Uganda. Journal of Refugee Studies, 29(3), 363-387. https://doi.org/10.1093/jrs/few010

Oslender, U. (2016). The banality of displacement: Discourse and thoughtlessness in the internal refugee crisis in Colombia. Political Geography, 50, 10-19. https://doi.org/10.1016/j.polgeo.2015.08.001

Phadera, L., Sharma, D., Wai-Poi, M. (2020). Iraq's Universal Public Distribution System: Utilization and Impacts During Displacement. World Bank policy research working paper 9155. https://documents1.worldbank.org/curated/en/239031582135436157/pdf//raqsUniversal-Public-Distribution-System-Utilization-and-Impacts-During-Displacement.pdf

Protection Cluster. (2020). Self-reported barriers to activities of daily living of persons with disabilities living in IDP sites in northwest Syria: Lived experiences of persons with sensory, physical, and cognitive difficulties residing in unfinished buildings, collective centres, makeshift tents and formal camps. https://www.humanitarianresponse.info/sites/www.humanitarianresponse.info/files/docum ents/files/protection_cluster_syria_turkey_self-

reported_barriers_persons_with_disabilities_final_29112020.pdf

Rae, F. (2011). Border-controlled health inequality: The international community's neglect of internally displaced persons. Medicine, Conflict and Survival, 27(1), 33-41. https://doi.org/10.1080/13623699.2011.562396

Saieh, A. (2019). Barriers from birth: Undocumented children in Iraq sentenced to a life on the margins. Norwegian Refugee Council. https://www.nrc.no/globalassets/pdf/reports/iraq/barriers-from-birth/barriers-from-birthmed-pages.pdf

Tull, K. (2019). Civil documentation for Internally Displaces Persons (IDPs) in protracted displacement.

IDS. https://opendocs.ids.ac.uk/opendocs/bitstream/handle/20.500.12413/14626/636_Civil_Do cumentation\%20_for_IDPs.pdf?sequence=1\&isAllowed=y

UNICEF. (2019). Protecting and supporting internally displaced children in urban settings. https://www.unicef.org/media/56191/file/Protecting\%20the\%20rights\%20of\%20internally \%20displaced\%20children.pdf

World Bank (2017). Forcibly Displaced: Towards a development approach supporting refugees, the internally displaced, and their hosts. World Bank. https://openknowledge.worldbank.org/handle/10986/25016 


\section{Acknowledgements}

We thank the following experts who voluntarily provided suggestions for relevant literature or other advice to the author to support the preparation of this report. The content of the report does not necessarily reflect the opinions of any of the experts consulted.

- $\quad$ Bayard Roberts, London School of Health and Tropic Medicine.

\section{Suggested citation}

Kelly, L. (2021). Policy and administrative barriers to IDPs accessing basic services. K4D Helpdesk Report. Institute of Development Studies. DOI: 10.19088/K4D.2021.112

\section{About this report}

This report is based on six days of desk-based research. The K4D research helpdesk provides rapid syntheses of a selection of recent relevant literature and international expert thinking in response to specific questions relating to international development. For any enquiries, contact helpdesk@k4d.info.

K4D services are provided by a consortium of leading organisations working in international development, led by the Institute of Development Studies (IDS), with Education Development Trust, Itad, University of Leeds Nuffield Centre for International Health and Development, Liverpool School of Tropical Medicine (LSTM), University of Birmingham International Development Department (IDD) and the University of Manchester Humanitarian and Conflict Response Institute (HCRI).

This report was prepared for the UK Government's Foreign, Commonwealth and Development Office (FCDO) and its partners in support of pro-poor programmes. Except where otherwise stated, it is licensed for non-commercial purposes under the terms of the Open Government Licence v3.0. K4D cannot be held responsible for errors, omissions or any consequences arising from the use of information contained in this report. Any views and opinions expressed do not necessarily reflect those of FCDO, K4D or any other contributing organisation.

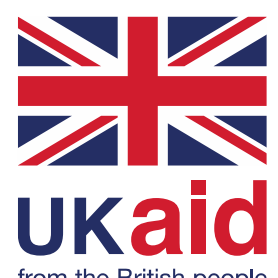

(C) Crown copyright 2021. 